\title{
Effects of Intraruminal Administration of Lactic Acid on Mineral Concentrations in Rumen Fluid of Steers
}

\author{
Yoshiaki Terashima, Shigeru Terashita, \\ Nobuhito TohraI and Hiroshi ITOH \\ Department of Animal Science, Kitasato University, Towada-shi 034
}

(Received August 29, 1975)

\begin{abstract}
The $\mathrm{pH}$ of rumen fluid was manipulated by intraruminal administration of lactic acid, acetic acid and hydrochloric acid (1 liter of 2 mol solution) and changes in soluble $\mathrm{Ca}, \mathrm{Mg}, \mathrm{P}, \mathrm{Na}$ and $\mathrm{K}$ were investigated at roughage feeding period in steers fitted with rumen fistula. Lactic acid, ammonia nitrogen and VFA content in the rumen fluid as well as lactic acid level of the blood serum were determined with the infusion of $4 \mathrm{~mol}$ lactic acid solution. In the rumen fluid the lowest $\mathrm{pH}$ was observed $30 \mathrm{~min}$ after the acid infusion; 4.4 with hydrochloric acid, 5.9 with lactic acid and 6.2 with acetic acid. Concomitantly, when expressed in concentration, soluble $\mathrm{Ca}$ and $\mathrm{Mg}$ were almost doubled, $\mathrm{P}$ was slightly increased and $\mathrm{Na}$ and $\mathrm{K}$ were remained unchanged. There were highly significant correlations between $\mathrm{pH}$ in the rumen fluid and concentrations of $\mathrm{Ca}$ and $\mathrm{Mg}$. The lactic acid concentration of rumen fluid, which was less than $1 \mathrm{mg} / 100 \mathrm{~m} l$ in steers fed the roughage, increased to about $12 \mathrm{mg} / 100 \mathrm{~m} l$ $30 \mathrm{~min}$ after the lactic acid infusion and rapidly decreased thereafter. The ammonianitrogen content of the rumen fluid increased after feeding and showed further increase after lactic acid infusion. The latter treatment caused a decrease of acetic acid, increases of propionic and butyric acids in the fluid, and an elevation of lactic acid level in the blood serum. The increases of soluble $\mathrm{Ca}, \mathrm{Mg}$ and $\mathrm{P}$ were also evident when acids were added in vitro fermentation trials which were carried out to analyze the results of in vivo tests. The concentration of $\mathrm{Na}$ and $\mathrm{K}$ was again unchanged by the addition of acids in vitro. The results as a whole favor a view that lactic acid produced in the rumen might increase availability of some important minerals in the digesta and thereby participate mineral metabolism of the ruminants.
\end{abstract}

The pattern of rumen fermentation with ruminants fed the high grain ration is different from that fed the roughage. Several experiments ${ }^{1-8}$ have shown that the production of lactic acid in the rumen increased with feeding of the high grain ration. It has been known that concentrations of minerals in rumen fluid are affected by dietary levels and salivary supply of minerals according to the kinds of ration fed ${ }^{4-7)}$. In our previous reports, ${ }^{8,9}$ ) it was suggested that the absorption of $\mathrm{Ca}, \mathrm{P}$ and $\mathrm{Mg}$ from the digestive tract of sheep fed the high grain ration will increase in comparison with that fed the the roughage. It seems that the lactic acid produced in the rumen with the high grain ration feeding may affect the mineral concentration in rumen fluid and subsequently participate the mineral metabolism of ruminants.

The experiment reported here was conducted to clarify the relationship between the changes of mineral metabolism and increased lactic acid in rumen induced by the high grain ration feeding by the administration of lactic acid into the rumen of animals fed the roughage. Concentrations of some important minerals in rumen fluid of steers fed the roughage were determined by intraruminal infusion of lactic, acetic and hydrochloric acid solutions. Lactic acid, total VFA and ammonia-nitrogen $\left(\mathrm{NH}_{\mathrm{g}}-\mathrm{N}\right)$ in the rumen fluid and lactic acid in the blood serum 


\section{Ruminal Mineral Concentration and Lactic Acid}

were determined with the intraruminal administration of lactic acid. The in vitro fermentation trial was also conducted to analyze the results of in vivo tests.

\section{Materials and Methods}

Two steers (average body weight; $391 \mathrm{~kg}$ ) fitted with permanent rumen fistula were used. Ten $\mathrm{kg}$ of orchardgrass hay was divided into two equal portions and was give at 9:00 and 16:00, respectively. The proximate analysis of the orchardgrass hay showed moisture 11.9, crude protein 10.4, crude fat 3.6, nitrogen free extract 38,9 , crude fiber 26.2 , and crude ash 9.0 percent, and the content of $\mathrm{Ca}, \mathrm{Mg}, \mathrm{P}, \mathrm{Na}$ and $\mathrm{K}$ was $0.26,0.24,0.30,0.02$, and 2.17 percent, respectively. Water was freely available. The ration was consumed within 2.5 hours after feeding. Each quarter of 1 liter of $2 \mathrm{~mol}$ solutions of racemic lactic acid, acetic acid and hydrochloric acid warmed at $39^{\circ} \mathrm{C}$ was infused into the center part of rumen content using the long legged polyethylen funnel through rumen fistula with about $5 \mathrm{~min}$ intervals at 11:30, 2.5 hours after feeding. Deionized water ( 1 liter) was administered as the control. The administration of each acid was triplicated and the control trial was duplicated with two days intervals. About $100 \mathrm{~m} l$ of rumen fluid was taken at 9:00,11:30,12:00,13:00, 14:00 and 16:00. The fluid was filtrated through a double cheese cloth layer and centrifuged to obtain the supernatant for determining the mineral concentration. Since no difference was found between concentrations of mineral in the supernatant of rumen fluid treated by the method of $10,000 \mathrm{rpm}$ for $60 \mathrm{~min}$ and $3,000 \mathrm{rpm}$ for $15 \mathrm{~min}$, the latter method was used in this experiment. Minerals in this supernatant are regarded as the soluble ones. An aliquot of the supernatant was digested with the mixed acid $\left(\mathrm{HNO}_{8} ; 3, \mathrm{H}_{2} \mathrm{SO}_{4} ; 1, \mathrm{HClO}_{4} ; 1\right)$, made to volume with water and mineral contents were determined. The other duplicate trials were conducted with deionized water as the control and the $4 \mathrm{~mol}$ lactic acid solution and contents of lactic acid were determined on the blood serum and rumen fluid and that of VFA and $\mathrm{NH}_{3}-\mathrm{N}$ were also estimated on the rumen fluid. The blood samples of steers were taken from the jugular vein at the same time of rumen fluid sampling.

In the in vitro fermentation trial the ground orchardgrass hay passed through $1 \mathrm{~mm}$ screen was used as the substrate. Thirty $\mathrm{m} l$ of the filtrated rumen fluid taken before feeding at 9:00 AM was added to the incubation tube containing $0.5 \mathrm{~g}$ of the substrate. The tube was saturated with carbon dioxide and attached with a Bunsen valve and then placed at $39^{\circ} \mathrm{C}$ for 2.5 hours. Following this pre-incubation period, $1 \mathrm{~m} l$ of each acid solution was added into the tube and the incubation was further continued for 1 hour. Afte the incubation, the mineral content was determined by the method ${ }^{\mathrm{B}}$ ) previously reported. Sodium and $\mathrm{K}$ contents were determined using an atomic absorption spectrometer ${ }^{10}$ (Model no. 208, Hitachi). Phosphorus content was determined colorimetrically. ${ }^{11)}$ The $\mathrm{pH}$ of supernatant was estimated by a $\mathrm{pH}$ meter, and total VFA was determined by the steam distillation method ${ }^{12)}$ and each VFA was measured by the gas chromatography ${ }^{13)}$ ( $\mathrm{K} 53$ type, Hitachi). Lactic acid and $\mathrm{NH}_{\mathbf{3}}-\mathrm{N}$ contents were estimated by the method of Barker and SUMmerson ${ }^{14}$ ) and ConWaY ${ }^{15)}$, respectively.

\section{Results and Diseussion}

Changes of the $\mathrm{pH}$ and mineral concentrations of rumen fluid as a function of time after administration of acids are shown in Fig. 1. Data of the control are shown as average of that obtained at the experimental periods of 2 and $4 \mathrm{~mol}$ acid administration. The $\mathrm{pH}$ in the control 
trial was not affected by feeding and water infusion.

In acid trials the greatest fall of the $\mathrm{pH}$ was found at $30 \mathrm{~min}$ after adminstration, and the lowest $\mathrm{pH}$ value was observed with hydrochloric acid (4.4), followed by lactic acid (5.9) and acetic acid (6.2). Thereafter it gradually increased and returned to the initial value in 4.5 hours after dose. This experiment showed that lactic acid rather affected on the $\mathrm{pH}$ of rumen fluid than acetic acid, a main component of VFA, with the same molar concentration.

Calcium, $\mathrm{Mg}$ and $\mathrm{K}$ concentrations of rumen fluid increased after feeding and $\mathrm{Na}$ decreased,

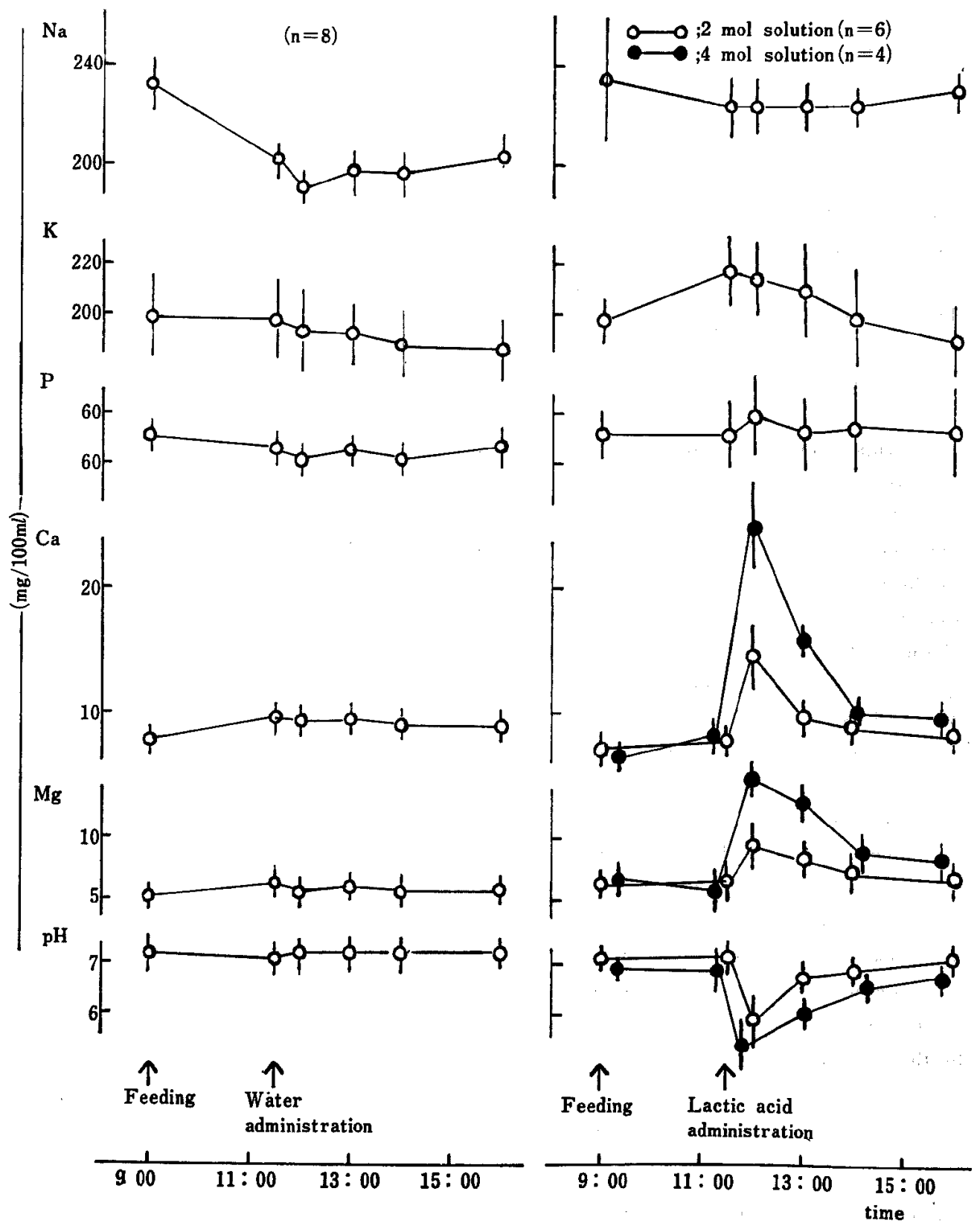

Fig. 1 (a). Changes of the $\mathrm{pH}$ and mineral concentrations in the rumen fluid (Mean $\pm \mathrm{SE}$ ) 


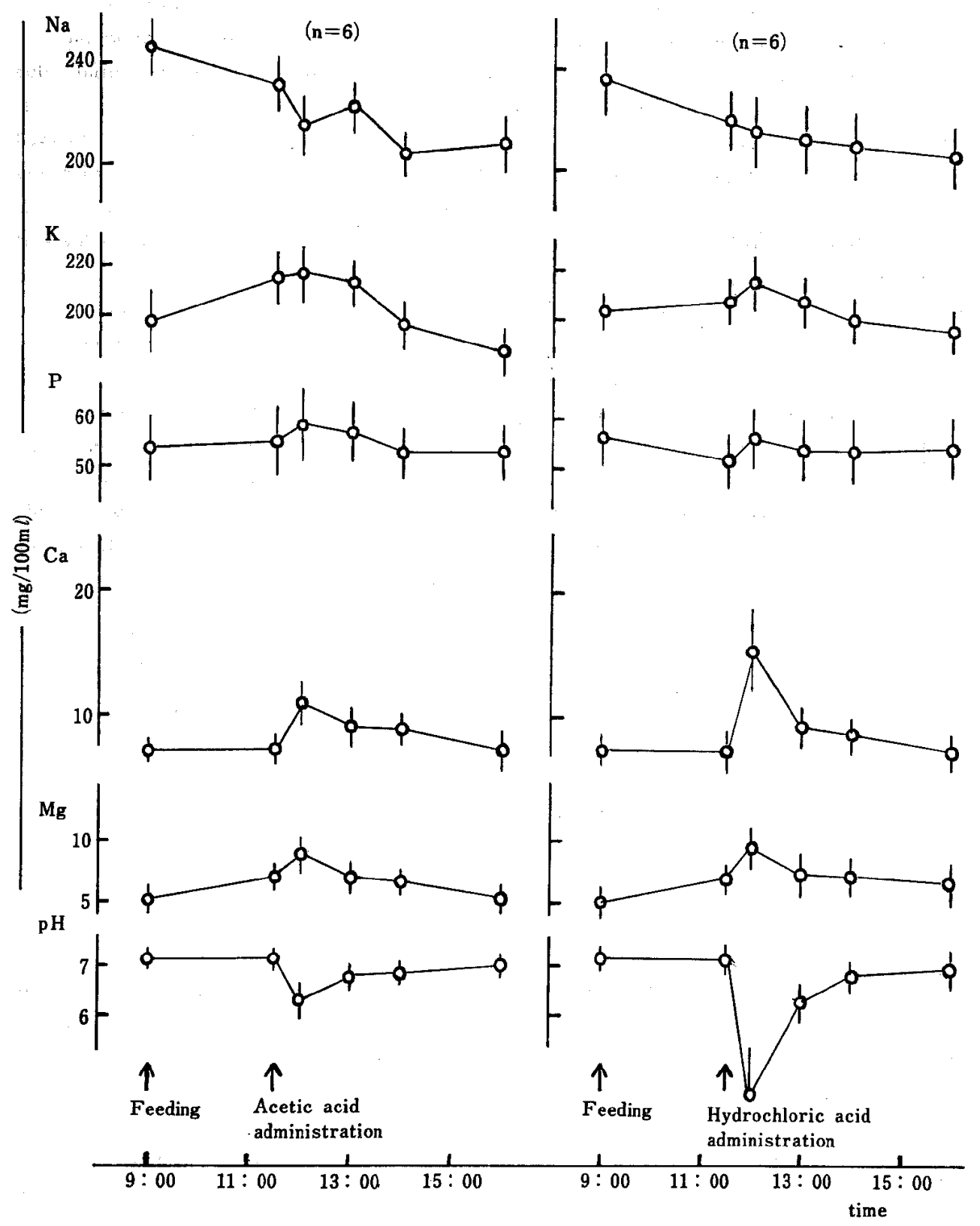

Fig. 1 (b). Changes of the pH and mineral concentrations in the rumen fluid (Mean \pm SE)

and $\mathrm{P}$ varied slightly. It is assumed that the increase of $\mathrm{Ca}, \mathrm{Mg}$ and $\mathrm{K}$ are mainly affected by the dietary intake. It has been known that Na concentration in rumen fluid is more influenced by saliva than feed ingested ${ }^{16-18}$. It appears that the decrease of $\mathrm{Na}$ concentration after feeding is resulted from the low secretion of saliva according to the active fermentation in the rumen and it agrees with the observations by SAwA et $a l .{ }^{6)}$ and BAILEY. ${ }^{18)}$

After the acid infusion, the following changes of mineral concentrations were observed. Water infusion in the control trial gave no changes in concentration of each mineral through 
the experimental period. Administration of acids highly increased the concentration of $\mathrm{Ca}$ and $\mathrm{Mg}$ in the rumen fluid during $30 \mathrm{~min}$ and levels of soluble $\mathrm{Ca}$ and $\mathrm{Mg}$ showed approximately 2 times of the initial value. Thereafter it gradually decreased and returned to the initial value at 16:00. The extent in changes of mineral concentrations were differed with the kind of acids administered and reversely corresponded with the changes of $\mathrm{pH}$ value. It has been observed that concentrations of $\mathrm{Ca}$ and $\mathrm{Mg}$ in rumen fluid are mainly raised by the dietary supply ${ }^{5}$ and the amounts of these water soluble minerals in the digestive tract are affected by the $\mathrm{pH}$ value $^{19}$. It is assumed, therefore, that the acidification of rumen fluid shown as the lowered $\mathrm{pH}$ value by the acid administration increase the solubility of these minerals in digesta and the amount of soluble minerals in rumen fluid. The $P$ concentration of rumen fluid was slightly varied with the acid administration. It has been reported that $\mathrm{P}$ concentration is generally affected by the feed intake and salivary secretion ${ }^{5,20)}$ with narrow variation ${ }^{6)}$. It is considered that the slight increase of $P$ in rumen fluid in this experiment is resulted from the increased solubility of $\mathrm{P}$ of feed and digesta in the rumen. As it has been known that the concentration of $\mathrm{Na}$ in rumen fluid is mainly affected by saliva ${ }^{(, 17)}$ and $\mathrm{K}$ is by saliva and feed ingested ${ }^{6}$, it seems that less affection by acid administration on concentrations of both minerals in this experiment shows no influence of acid infusion on the secretion of saliva and the solubility of these minerals in digesta.

Table 1. The correlation coefficient between mineral concetrations and the $\mathrm{pH}$ in the rumen fluid with the acid administration $(n=36)$

\begin{tabular}{lccc}
\hline \hline Acid & Lactic acid & Acetic acid & Hydrochloric acid \\
\hline Mineral & $-0.92^{* *}$ & $-0.79^{* *}$ & $-0.87^{* *}$ \\
$\mathrm{Ca}$ & $-0.34^{*}$ & $-0.36^{*}$ & 0.05 \\
$\mathrm{P}$ & $-0.63^{* *}$ & $-0.71^{* *}$ & $-0.68^{* *}$ \\
$\mathrm{Mg}$ & 0.02 & 0.22 & 0.16 \\
$\mathrm{Na}$ & -0.24 & 0.04 & -0.14 \\
$\mathrm{~K}$ & & & \\
\hline
\end{tabular}

**: $\mathrm{P}<.001 \quad *: \mathrm{P}<.05$

The coefficients of correlation between the $\mathrm{pH}$ value and the concentration of each mineral in rumen fluid after the acid administration are shown in Table 1. The negative correlation on $\mathrm{Ca}$ and $\mathrm{Mg}$ concentration was significantly high with all the acids administered $(\mathrm{P}<.001)$. These results suggested that concentrations of these minerals were mainly affected by the rumen $\mathrm{pH}$. The correlation between $\mathrm{P}$ and $\mathrm{pH}$ value was significant with the lactic and acetic acid administration $(P<.05)$, and not significant with hydrochloric acid. There was little correlation between $\mathrm{K}$ and $\mathrm{Na}$ concentration and the $\mathrm{pH}$ value with all the acid administered.

Changes of the $\mathrm{pH}$ value and the concentration of $\mathrm{Ca}$ and $\mathrm{Mg}$ are shown in Fig. 1 with the administration of $4 \mathrm{~mol}$ lactic acid solution. The more decrease of $\mathrm{pH}$ and more increase of these mineral concentrations occurred as compared with the infusion of 2 mol lactic acid. Concentration of lactic acid, $\mathrm{NH}_{3}-\mathrm{N}$, total VFA and individual VFA in rumen fluid and of lactic acid in blood serum are shown in Figs. 2 and 3. These values were also determined on the sample of the control trial at the period of $4 \mathrm{~mol}$ acid administration. The lactic acid concentration of rumen fluid in the control trial showed a constant level and was less than 1 $\mathrm{mg}$ per $100 \mathrm{~m} l$, and that in the lactic acid trial markedly increased and attained to about $12 \mathrm{mg}$ at $30 \mathrm{~min}$ after infusion. Subsequently it gradually declined to about $3 \mathrm{mg}$ per $100 \mathrm{~m} l$ at 16:00. 

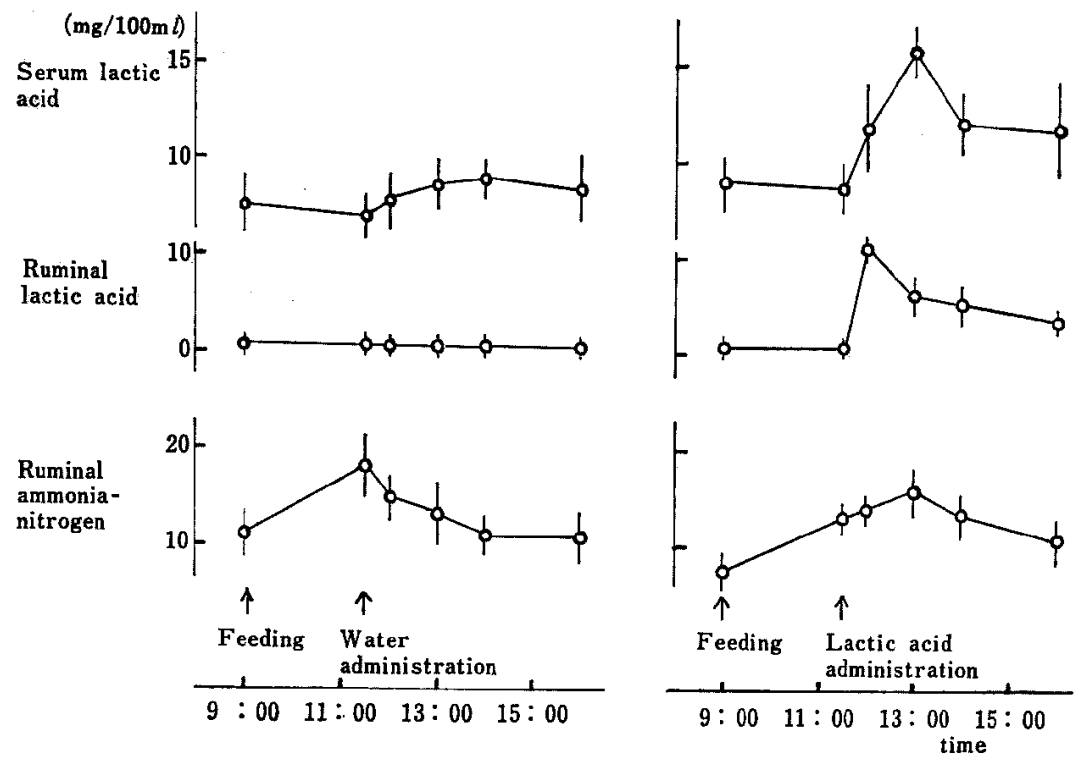

Fig. 2. Changes of the ammonia-nitrogen and lactic acid content in the rumen fluid and the level of serum lactic acid with $4 \mathrm{~mol}$ lactic acid administration (Mean $\pm \mathrm{SE}, n=4$ )
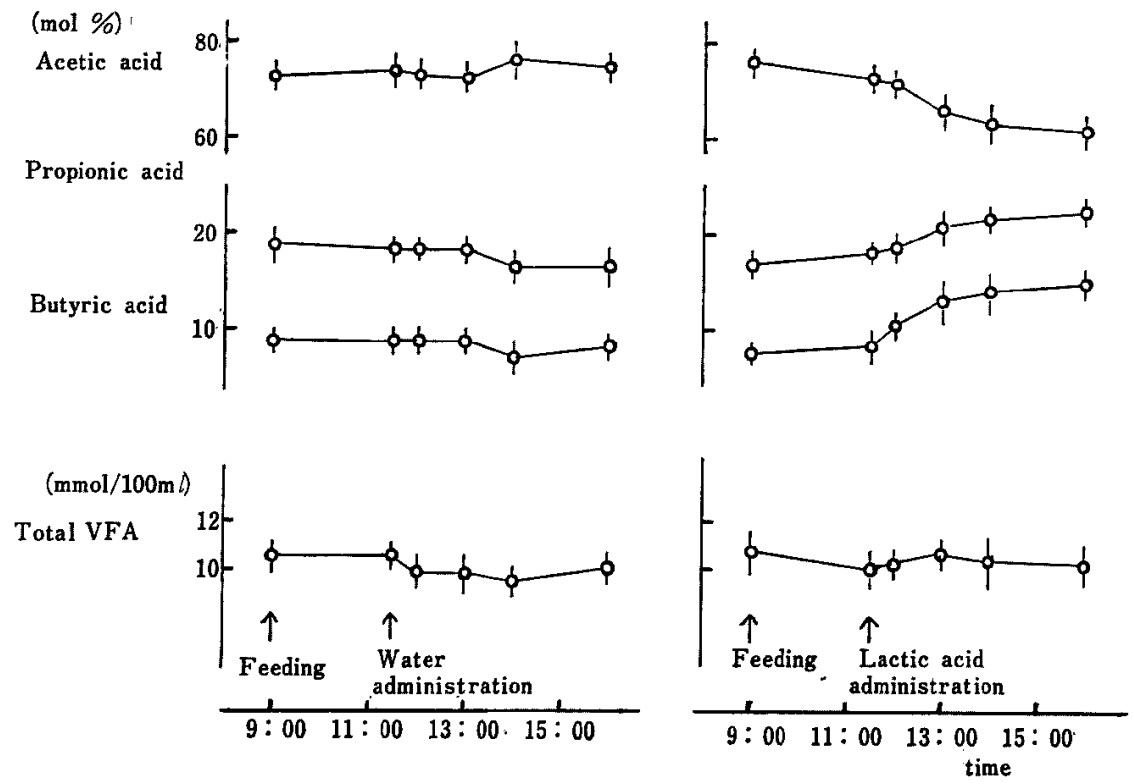

Fig. 3. Changes of total VFA and individual VFA contents in the rumen fluid with 4 mol lactic acid administration (Mean $\pm \mathrm{SE}, n=4$ )

The level of lactic acid in blood serum increased with the acid administration into the rumen and the highest value which was approximately 2 times higher than that of the control was found at 13:00. It seems that these changes are resulted from the conversion of lactic acid to other products, namely propionic acid in the rumen and the absorption of lactic acid from rumen wal191-24). Level of $\mathrm{NH}_{3}-\mathrm{N}$ in the rumen fluid increased after feeding and the highest 
value was found at 11:30 and it increased moreover after the acid administration. Total VFA and the ratio of individual VFA in rumen fluid remained constant in the control. The molar percent of acetic acid markedly decreased with increase of propionic and butyric acids with the acid administration. The increased ratio of propionic and butyric acid in this experiment seemed to be resulted from high conversion of lactic acid ${ }^{26,28)}$.

Table 2. The $\mathrm{pH}$ and mineral concentrations $(\mathrm{mg} / 100 \mathrm{ml})$ in the rumen fluid at 1 hour after the acid administration (In vitro trial, mean of three determinations)

\begin{tabular}{ccccccc}
\hline Treatment & $\mathrm{pH}$ & $\mathrm{Ca}$ & $\mathrm{P}$ & $\mathrm{Mg}$ & $\mathrm{Na}$ & $\mathrm{K}$ \\
\hline $\begin{array}{c}\text { Control } \\
\text { (Water) }\end{array}$ & 6.9 & 9.2 & 63.9 & 9.5 & 175 & 219 \\
$\begin{array}{c}\text { Lactic acid } \\
(2 \mathrm{~mol})\end{array}$ & 5.5 & 10.6 & 68.0 & 10.3 & 171 & 222 \\
$\quad(4 \mathrm{~mol})$ & 4.6 & 11.7 & 69.0 & 10.6 & 176 & 223 \\
$\begin{array}{c}\text { Acetic acid } \\
(2 \mathrm{~mol})\end{array}$ & 5.4 & 10.2 & 71.6 & 10.3 & 173 & 222 \\
$\quad(4 \mathrm{~mol})$ & 4.9 & 10.8 & 68.8 & 10.5 & 176 & 222 \\
$\begin{array}{c}\text { Hydrochloric acid } \\
(2 \mathrm{~mol})\end{array}$ & 5.0 & 10.4 & 70.3 & 10.5 & 176 & 220 \\
$\quad(4 \mathrm{~mol})$ & 4.2 & 11.7 & 70.5 & 10.8 & 176 & 223 \\
\hline
\end{tabular}

The variations of mineral concentrations with each acid addition in vitro fermentation trial are shown in Table 2. Concentrations of $\mathrm{Ca}, \mathrm{P}$ and $\mathrm{Mg}$ in rumen fluid after incubation were higher with the addition of $2 \mathrm{~mol}$ solution of acid compared to that of the control. Sodium and $\mathrm{K}$ concentrations were not influenced by the acid addition. The further decrease of the $\mathrm{pH}$ value and increase of concentration of $\mathrm{Ca}, \mathrm{P}$ and $\mathrm{Mg}$ were observed when the 4 mol solution of acid was added. Changes of the $\mathrm{pH}$ value and mineral concentration were differed with the kind of acid added and those were similar to that found in vivo trials. The lowered increasing rate in vitro trial seems to be resulted from the limit of supplying the substrate. It seems that the increased soluble minerals observed with the acid administration are derived from the substrate and rumen fluid owing to the increased solubility of minerals without any affection by salivary supply. The change of $\mathrm{P}$ concentration contributed by the acid addition was smaller than that of $\mathrm{Ca}$ and $\mathrm{Mg}$, and concentrations of $\mathrm{Na}$ and $\mathrm{K}$ were not affected by the $\mathrm{pH}$ value varied with the acid administration.

It is evident therefore that the lactic acid administered into the rumen of steers fed the roughage temporarily lowered the $\mathrm{pH}$ value of rumen fluid and subsequently increased the concentration of $\mathrm{Ca}, \mathrm{P}$ and $\mathrm{Mg}$ of rumen fluid and further increased the lactic acid level in blood serum. It was observed in our previous experiments ${ }^{8,9)}$ that the absorption and urinary excretion of $\mathrm{Ca}, \mathrm{P}$ and $\mathrm{Mg}$ in sheep fed the high grain ration was significantly higher than that of sheep fed the roughage, suggesting that the absorption of these minerals from the digestive tract would be more stimulated when sheep was fed the high grain ration. It is assumed therefore that the continual production of lactic acid in the rumen of animal fed the high grain ration would play an important role on mineral metabolism as same to the observations found with the intraruminal administration of lactic acid for animals fed the roughage. 


\section{References}

1) Briggs, P.K., J.P. Hogan, and R. L. Reid, Aust J Agric Res 8: 674-690. 1957.

2) Grorban, K. Z., K.L. Knox, and G. M. Ward, J Dairy Sci 49: 1515-1518. 1966.

3) Dunlop, R. H., and P.B. Hammond, Ann N Y Acad Sci 119: 1109-1132. 1965.

4) Poutiainen, E., Ann Agric Fenn 9: 347-356. 1970.

5) Poutiainen, E., Ann Agric Fenn 10: 14-24. 1971.

6) SaWA, A., T. Senshu, and T. Matsumoto, Jap J Zootech Sci 45: 387-395. 1974.

7) Yano; F., R. Kawashima, and S. Uesaka, Bull Res Insti Food Sci Kyoto Uni. 34: 1-8. 1971.

8) Terashima, Y., and H. Itoh, Jap J Zootech Sci 46: 257-262. 1975.

9) Terashima, Y., I. ShinozAKI, N. Tohrai, and H. ItoH, Jap J Zootech Sci 46: 263-268. 1975.

10) Willis, J. B., Spectrochim Acta 16: 551-558. 1960.

11) Kutter, T. and H.R. Cohen, J Biol Chem 75: 517-531. 1927.

12) Friedemann, T.E., J Biol Chem 123: 161-183. 1938.

13) Kromann, R.P., J. H. Meyer, and W. J. Stiglau, J Dairy Sci 50: 73-76. 1967.

14) Barker, S. B., and W. H. Summerson, J Biol Chem 138: 538-554. 1941.

15) Conway, E. J., Microdiffusion Analysis and Volumetric Error. London: Crosby Lockwood. 1957.

16) McDougall, E. J., Biochem J 43: 99-109. 1948.

17) Poutiainen, E., Ann Agric Fenn 7 Suppl 3: 1-66. 1968.

18) BaIley, C. B., Brit J Nutr 15: 489-498. 1961.

19) Ben-Ghedalia, D., H. Tagari, S. Zamvel, and A. Bondi, Brit J Nutr 33: 87-94. 1975.

20) Tomas, F. M., Quart J Exp Physiol 58: 131-138. 1973.

21) Heuter, F. G., J.C. Shaw, and R. N. Doetsch, J Dairy Sci 39: 1430-1437. 1956.

22) WaLdo, D. R., and L.H. Schultz, J Dairy Sci 43: 496-505. 1960.

23) Williams, V. J., and D.D.S. Mackenzie, Aust J Biol Sci 18: 917-934. 1965.

24) Trlle, P. P., and R. L. Preston, J Anim Sci 33: 698-705. 1971.

25) Tremere, A.W., W.G. Merrili, and J. K. Loosti, J Dairy Sci 51: 1065-1072. 1968.

26) LADD, J. N., and D. J. WaLKER, Ann N Y Acad Sci 119: 1038-1047. 1965. 


\title{
ルーメン液の無機物濃度に対する乳酸投与の影響
}

\author{
寺島福秋・寺下 茂・唐来宣人・伊藤 厷
}

北里大学畜産学部，十和田市 034

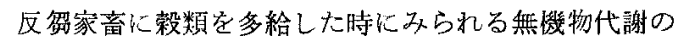
変化と，ルーメン内で産生が高まる乳酸との関係を解明 するため, 乳酸産生の低い粗飼料給与時のルーメン内に 乳酸を投与する実驗を行った。オーチャードダラス乾草 給与のルーメンフィステル装着牛穵用い,フィステルよ り乳酸，酶酸および塩酸 ( 2 モル溶液, 1 liter $)$ をルーメ ン内に直接投与し，ルーメン液の亜機物濃度および $\mathrm{pH}$ 值の变化ならびに 4 モル乳酸溶液投与時のルーメン液の 乳酸, アンモニア態窒装, 全VEA 量, 各VFA モル比 および血中乳酸量を経時的に測定した。またin vitro 試 験法による各酸添加と培咅液の無機物濃度との関係につ いて in vivo での成績上比較した.

ルーメン液の $\mathrm{pH}$ 值は酸の投与により急激に低下し (酢酸； 0.9 , 乳酸: 1.3 , 塩酸； $2.6 \mathrm{pH}$ 単位低下), 投与 後 30 分で最低值を示しその後徐々に上昇して投与後 4.5 時間にほぼ投与前の值になった。ルーメン夜の Ca 於よ び $\mathrm{Mg}$ 嶩度はルーメン液 $\mathrm{pH}$ 值の変化と高い相関を持っ て変化し，酸の投与後 30 分に投与前の約 2 倍に急増し,
その後 $\mathrm{pH}$ 值の上昇に伴なって減少し，投与後 4.5 時間 にほぼ投与前の值になった。P溇度は $\mathrm{Ca}$ および $\mathrm{Mg}$ と

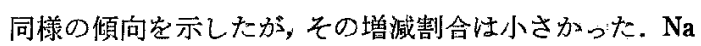
および K 濃度の酸投与による変化はさらに小さく, $\mathrm{pH}$ の変化による影䍌は認められな放った， 4 モル乳酸液投 与時の $\mathrm{Ca}$ お゙よび $\mathrm{Mg}$ 濃度は 2 モル乳酸液の場合より高 い値を示した。ルーメン液の乳酸濃度は投与後; 特間の 経過と共に減じたが，プロピオン酸および酪酸は增加す る傾向を示した。血中乳酸浱度は乳酸投与後若干增加し

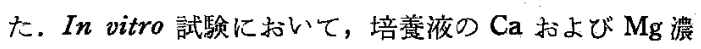
度は，酸の添加量を增加するに従って上昇し，飼料汃ら の無機物溶出量およびルーメン液の可溶性無機物濃度が 增大することを明らかに示したが，この濃度の増加割合： 恃，in vivo の成績と比較して低いものであった，桂類 多給時のルーメン内乳酸産生量の增加はルーメン液の. 主要無機物䟴度および血液乳酸 量の增加を介して, 反 羿家畜の無機物代謝に影響を与えているものと考元ら れた。 